\title{
Effect of Four Levels of Fertilization on Beef Production and Carrying Capacity of Pangola Grass Pastures in the Humid Mountain Region of Puerto Rico, ${ }^{1,2}$
}

\author{
Rubén Caro-Costas, José Vicente-Chandler, and Fernando Abruña ${ }^{3}$
}

\section{INTRODUCTION}

Caro and Vicente-Chandler (2) found that Napier grass pastures on steep slopes in the humid mountain region of Puerto Rico responded strongly in terms of beef production and carrying capacity to applications of up to 2,000 pounds of 14-4-10 fertilizer per acre yearly. Caro, VicenteChandler and Figarella (3) found that in this region Pangola, Guinea and Napier grass pastures receiving 2,000 pounds per acre of 14-4-10 fertilizer produced similar yields averaging 1,065 pounds of gain in weight per acre yearly.

Pangola (Digitaria decumbens) is the most widely used pasture grass in the humid mountain and coastal regions of Puerto Rico. Vicente-Chandler, Figarella and Silva (4) determined the effects of harvest interval and nitrogen fertilization on yield and composition of Pangola grass harvested by cutting. There is little information, however, on the response of Pangola grass to fertilization under actual grazing conditions in the humid region of Puerto Rico.

The present study determined the effect of four levels of fertilization on beef production and carrying capacity of Pangola grass pastures over a 2year period in the humid mountain region of Puerto Rico.

\section{MATERIALS AND METHODS}

The experiment was carried out near Orocovis, which has a mean annual temperature of about $75^{\circ} \mathrm{F}$, and a seasonal variation of less than $10^{\circ} \mathrm{F}$. Annual rainfall during the experiment averaged about 70 inches and was well distributed throughout the year except for a dry period from January

1 Manuscript submitted to Editorial Board September 28, 1971.

2 This paper reports the results of research conducted cooperatively between the Soil and Water Conservation Research Division, Agricultural Research Service, USDA, and the Agricultural Experiment Station, Mayagïez Campus, University of Puerto Rico, Río Piedras, P.R.

3 Agronomist, cooperative between SWCRD, ARS, USDA, and the Agricultura] Experiment Station, Mayagïez Campus, University of Puerto Rico; and Project Leader-Soil Scientist and Soil Scientist, Soil and Water Conservation Research Division, ARS, USDA, respectively, Río Piedras, P.R. 
through March. The soil is deep, red, acid, well-drained Humatas clay (Ultisol) with an average slope of 25 percent.

Fertilizer levels of $400,1,200,2,400$ and 3,400 pounds of $14-4-10$ per acre yearly were applied in four equal applications at 3-month intervals. All treatments were replicated 4 times in a randomized block design using sixteen $1 / 2$-acre pastures. The pastures were limed to about $\mathrm{pH} 5.5$ and were provided with water and salt. They were not weeded or mowed during the experiment.

The pastures were grazed by young Holstein heifers initially weighing about 400 pounds, which were replaced every 12 months. The cattle, treated periodically for parasites and well cared for, received no feed other than that obtained from the pastures. The "tester" cattle which were to remain on the pastures for a full year were divided into four groups, one for each level of fertilization. One-half, $1,1 \frac{1}{2}$, and 2 "testers" were kept per acre at all times on the pastures receiving $400,1,200,2,400$ and 3,400 pounds of fertilizer per acre yearly, respectively. Additional animals were added to each group as required to consume excess forage produced during scasons of flush growth using the well-known "put and take" method.

Cattle were weighed each time they were moved from one enclosure to another and a record was kept of grazing days, animal weights, and gains in weight for each pasture. The total digestible nutrients produced by each pasture were calculated from these data following recommendations of the Pasture Research Committee (1). On the average, the pastures were grazed for 1 week followed by a rest period of three weeks.

\section{RESULTS AND DISCUSSION}

Table 1 shows that the Pangola grass pastures responded in terms of liveweight production and carrying capacity, as well as economically, to applications of up to 2,400 pounds of 14-4-10 fertilizer per acre yearly, but there was no further significant increase due to heavier fertilization.

When 2,400 pounds of fertilizer were applied the Pangola grass pastures carried the equivalent of two 600-pound steers per acre with a minimum of $11 / 2$ head per acre on the pastures at all times. At this level of fertilization the pastures produced an average of 871 pounds of gain in weight worth about $\$ 260$ per acre yearly.

This productivity is somewhat less than would be expected since Caro, Vicente-Chandler, and Figarella (3) obtained 1,006 pounds of gain in weight per acre yearly from Pangola grass pastures receiving 2,000 pounds of fertilizer per acre yearly under similar conditions. This difference can be explained by the fact that during the present experiment many of the pastures were attacked by aphids to which Pangola grass is very suscep 
tible and were also invaded to some extent by lower yielding Para (Panicum purpurascens) grass, a common occurrence with Pangola grass pastures throughout much of the humid region of Puerto Rico.

Average daily gains per head of 1.2 pounds were similar for all treatments and are considered acceptable for growing animals on all-grass rations.

\section{SUMMARY}

Pungola grass pastures on sloping lands in the humid mountain region of Pucrto Rico responded in terms of beef production and carrying capacity, as well as economically, to applications of up to 2,400 pounds of 14-4-10 fertilizer per acre yearly, but there was no further significant increase due

TABLE 1.-Effect of 4 levels of fertilization on the produclivily of Pangola grass pastures on steep slopes in the humid mountain region near Orocoviss

over $\&$ consecutive years of grazing

\begin{tabular}{rccccc}
\hline $\begin{array}{c}\text { Fertilizer } \\
\text { (14-4-10) } \\
\text { applied per } \\
\text { acre yearly }\end{array}$ & $\begin{array}{c}\text { Gain in } \\
\text { weight per } \\
\text { acre yearly }\end{array}$ & $\begin{array}{c}\text { Increase in per } \\
\text { acre income after } \\
\text { deducting cost } \\
\text { of fertilization }\end{array}$ & $\begin{array}{c}\text { Total digest- } \\
\text { ible nutrients } \\
\text { produced per } \\
\text { acre yearly }\end{array}$ & $\begin{array}{c}\text { Carrying capa- } \\
\text { city (600. } \\
\text { pound steers } \\
\text { per acre) }\end{array}$ & $\begin{array}{c}\text { Minimum } \\
\text { number of } \\
\text { cattle per } \\
\text { acre }\end{array}$ \\
\hline Pounds & Pounds & Dollars & Pounds & Number & \\
400 & 355 & - & 2,348 & 0.76 & 0.50 \\
1,200 & 565 & 31.00 & 4,070 & 1.31 & 1.00 \\
2,400 & 871 & 74.80 & 6,235 & 2.01 & 1.50 \\
3,400 & 941 & 55.80 & 7,370 & 2.38 & 2.00 \\
\hline L.S.D.06 & 299 & - & 2,032 & .66 & \\
\hline
\end{tabular}

1100 pounds liveweight $=\$ 30.00$.

100 pounds of 14-4-10 including applications costs $=\$ 4.00$.

2 One 600-pound steer $=8.5$ lbs. T.D.N. daily.

to heavier fertilization over 2 years of experimentation. At the 2,400-pound rate of fertilization, Pangola grass pastures carried the equivalent of two 600 -pound steers per acre and produced an average of 871 pounds of gain in weight per acre yearly with average daily gains per head of 1.2 pounds.

\section{RESUMEN}

Pastos de yerba Pangola en la región húmeda montañosa de Puerto Rico respondieron favorablemente en términos de ganancia en peso, capacidad de pastoreo y económicamente a niveles de abonamiento de hasta 2,400 libras de la fórmula 14-4-10 por acre anualmente. Con la aplicación de 2,400 libras de abono por acre al año los pastos de Pangola alcanzaron una capacidad de pastoreo equivalente a dos novillos de 600 libras cada uno por acre, y produjeron un aumento de 871 libras en peso por acre al año durante 2 años consecutivos de pastoreo. Este aumento equivalió a 1.2 libras por cabeza al dia. 


\section{LITERATURE CITED}

1. Anonymous, Report on Pasture and Range Research Techniques Joint Committee of ASA, ASAP, ADSA, and ASRM, Agron. J. 44 (1): 39-50, 1952.

2. Caro-Costas, R., and Vicente-Chandler, J., Effect of fertilization on carrying capacity and beef produced by Napier grass pastures, Agron. J. 53: 204-5, 1961.

3. Caro-Costas, R., Vicente-Chandler, J., and Figarella, J., Productivity of intensively managed pastures of five grasses on steep slopes in the humid mountain region of Puerto Rico, J. Agr. Univ. P.R. 49 (1): 99-111, 1965.

4. Vicente-Chandler, J., Figarella, J., and Silva, S., Effects of nitrogen fertilization and frequency of cutting on the yield and composition of Pangola grass in Puerto Rico, J. Agr. Univ. P.R. 45 (1): 37-45, 1961. 